\title{
Screening for alcohol consumption for a worker health intervention
}

\author{
Riany Brites ${ }^{1 *}$, Ângela Maria Mendes de Abreu² \\ From INEBRIA 12th Congress, \\ Atlanta, GA, USA. 24-25 September 2015
}

\section{Background}

The World Health Organization has been pointing out that alcohol consumption is one of the serious public health problems at present, ranking third among leading health risk factors in the world. The consumption pattern of heavy and sporadic alcohol reaches $11.5 \%$ of alcohol consumers, accounting for serious health problems. In Brazil, the pattern of alcohol use has shown alarming rates in general on average are consumed six liters of pure alcohol per capita per year. So many workers abusively consume alcoholic beverages, due to lack of knowledge of its pattern of alcohol consumption and its consequences. In this context early detection of the pattern of alcohol consumption among workers, requires further investigation in order to enable better strategies for prevention and health promotion.

The objectives are to identify the pattern of alcohol consumption and to analyze the association between social and occupational profile of workers.

\section{Material and methods}

A descriptive study with 322 subjects who responded to the AUDIT (Alcohol Use Disorders Identification Test) and questions relating to the variables s social and occupational. Data were processed and analyzed using EpiInfo.

\section{Results}

It was observed that $87.3 \%$ were consumption of low risk and $12.7 \%$ made use of risk, harmful and likely dependency. The episodic heavy drinking was $32.5 \%$ and $5.3 \%$ have caused problems to themselves or others. Most do not consumed alcohol in the last 12 months, but those who consumed did in quantity and high frequency.

\section{Conclusions}

There was high prevalence of hazardous drinking, harmful and likely dependency associated with male workers and the low level of education. The sporadic heavy drinking was one of the information which alerted to the problem of alcohol consumption.

\section{Acknowledgements}

I thank my supervisor Angela Abreu, workers of the Federal University of Rio de Janeiro, friends of work for understanding and to everyone who contributed to the result of this work.

\section{Authors' details}

${ }^{1}$ Universidade Federal do Rio de Janeiro Rio de Janeiro, Brazil. Enfermagem de Saúde Pública Universidade Federal do Rio de Janeiro Rio de Janeiro, Brazil.

Published: 24 September 2015

\section{References}

1. ABREU Ângela MM: Mortalidade nos acidentes de transito na cidade do Rio de Janeiro relacionada ao uso e abuso de bebidas alcoólicas. Rio de Janeiro (RJ): Escola de Enfermagem Anna Nery/UFRJ; 2006, [tese de doutorado].

2. ACOSTA Laura Débora, FERNANDEZ Alicia Ruth, PILLON Sandra Cristina: Factores sociales para el uso de alcohol en adolescentes y jóvenes. Revista Latino-Americana de Enfermagem, Ribeirão Preto 2011, 19, Disponível em: . Acesso em: 08 Mar. 2012.

3. ALMEIDA LM, COUTINHO ESF: Prevalência do consumo de bebidas alcoólicas e de alcoolismo em uma região metropolitana do Brasil. In Revista de Saúde Pública. Volume 27. São Paulo; 1993:23-29.

4. AMARAL Régina Sélia Durães: O álcool é uma droga? Uma reflexão., Disponível em. Acesso em 23 de Nov.2010.

doi:10.1186/1940-0640-10-S2-P5

Cite this article as: Brites and de Abreu: Screening for alcohol consumption for a worker health intervention. Addiction Science \& Clinical Practice 2015 10(Suppl 2):P5.

* Correspondence: rianybrites.rb@gmail.com

1 Universidade Federal do Rio de Janeiro Rio de Janeiro, Brazil

Full list of author information is available at the end of the article 